\title{
Introduction: International Business Firms, Economic Development, and Ethics
}

\author{
Frederick Bird \\ Joseph Smucker \\ Manuel Velasquez
}

The purpose of this special issue is to illustrate how different social contexts present different ethical choices for international business firms. In considering social contexts, it is necessary to take a historical perspective. It is also necessary to take into account the important factors that confront international business firms, including local governments, local economic interests, and vested interest groups in local civil society (Smucker, 2006). The articles in this issue illustrate the different ways in which influences from these three sectors have come into play in challenging the operations of foreign firms in various social contexts. Ethical business practice is not merely a matter of avoiding disruptive intrusions into a national economy; it also involves the question of the degree to which investing firms are obligated to be a force for positive economic development and social enhancement.

Although the articles in this issue do not deal specifically with the composition of influences within individual firms, readers should bear in mind that business firms, especially those organized as corporations, are not free independent agents but rather are structures subject to the demands of different constituencies that contribute to their mode of operations: managers, directors, shareholders, employees, financial guarantors, and customers. It is necessary likewise to bear in mind that the type of direct investment made by international business interests is an important element in determining ethically responsible modes of operation. Foreign firms investing in mining operations, for example, face ethical issues quite different from those that confront firms investing in the manufacture of textiles or light equipment.

Bird's initial essay sets the tone for the case studies reported in this issue. He poses the general question of economic development as an ethical issue. More specifically, he explores the question of the responsibilities of business firms not only in furthering economic development, but also in advancing social enhancements and human development. Bird argues that these firms have a responsibility to increase the productive use of limited natural and human resources, to operate not as export-oriented enclaves but in ways that foster the economic growth of these areas as a whole, and to collaborate with local partners in establishing local physical, social, and economic infrastructures.

Naguib and Smucker's article, describes how the government policies of Malaysia, through successive 5 -year plans, dictated the terms of foreign investment and guided economic development toward the goal of ensuring that the economic and social returns were distributed in an equitable manner among the country's major ethnic groups. While not all of these policies fully realized the government's intended objectives, they did result in dramatic improvements in human and social capital, and reduced racially based inequities.

In contrast, Daye's article about Fiji reports the ongoing difficulties in achieving greater equality of opportunity between the two major racial and ethnic groups, Fijian and Indian. Past practices of foreign firms played a major role in creating the inequalities that still exist, and this has become an obstacle in attempts to achieve a more equitable society. Daye analyzes the current dilemmas of poverty and race relations, examining in particular the ways in which foreign firms have acted both to ameliorate and exacerbate these problems. The essay outlines both the opportunities and risks in doing business in Fiji.

In his account of the Freeport-Indonesia mining company, a subsidiary of the American company 
Freeport-McMoRan Copper and Gold, RifaiHasan examines the rather unsavory history of the company's operations in Indonesia and then describes the influence of local social movements in bringing about changes in the company's mode of operations. As a result of these pressures as well as government actions, the mining operations of the company were made to be more environmentally responsible and working conditions were vastly improved. Rifai-Hasan's account raises our awareness of the forces that have brought about change since the era when foreign firms could operate with near-impunity to the present time when these same firms are under increasing pressure to act in fair and equitable ways - including, in the case of this mining company, pressure to take concrete steps toward restoring the natural environment. Still, Freeport's power and influence, as Rifai-Hasan points out, have limited the central government's attempts to require even more socially responsible ways for the company to conduct its mining operations.

In the fifth article in this issue, Krueger provides a brief overview of recent Chinese economic developments and then points out five areas business firms should take into account if they are to operate in a profitable and responsible manner. These areas include (a) the role of government, which in the past has played an active interventionist role in the economy; (b) issues of transparency in both business and government operations; (c) the problem of reconciling unique cultural and ethical values with business objectives; (d) the question of improving human rights and ensuring adequate labor standards; and (e) the problem of minimizing the negative impact of ongoing development on the natural environment.

In each of the first five articles, government policies play an important role in defining the ethical terrain of business practices. It is clearly important to consider the responsibilities international business firms have with respect to government policies (Collier, 2007; Easterly, 2006). The payment of taxes is an example of obligations owed by business interests to the government. And yet firms continue to seek ways to evade these obligations through abusive forms of transfer pricing and distorted pricing schemes (Baker, 2005, chaps. 2-4; Collier, 2007, chap. 6.).

In cases where international business firms contract directly with governments for the right to operate, such firms must consider their ethical options should government policies violate the rights of local inhabitants or needlessly destroy the natural environment. The cases of Shell in Nigeria or the Talisman Corporation in the Sudan are examples of such ethical dilemmas: should these corporations cease operations, or are they in a position to bargain with the government in an effort to spread the returns of economic development in a more equitable manner (Bird, 2005). There may be instances when international businesses are obligated to take an ethical stand. One such example of influential ethical action occurred in South Africa during the apartheid era, when many international corporations subscribed to the Sullivan Principles protesting against racially based injustices (Sethi and Williams, 2001). With growing international awareness of the operations of international business firms, it is increasingly in their interests to promote the rule of law and strengthen legal institutions in developing areas. Perhaps the most effective means to accomplish these ends is through associations of business firms, thus eliminating undue costs for individual firms and minimizing the advantages of subsequent "free rider" firms.

The increased interest in establishing ethical standards is a marked departure from an earlier era, when subversive actions by private corporations helped undermine the governments of Chile, Iran, the Congo, Manchuria, and Guatemala. Increasingly observers have acknowledged that international business firms should abstain from such activities (Drohan, 2003, chap. 4; Kinzer, 2003; Klein, 2007, chaps. 3 and 4; Litvin, 2003, chaps. 3 and 4). Rather, they should seek to negotiate with governments in a transparent manner. Again, such actions would most likely have a positive effect if multiple firms acted in concert through associations.

In the sixth article, Velasquez introduces another aspect of international investment: the conduct of business operations through linkages with indigenous firms. Here, the author provides an account of the quite remarkable policies of Hewlett-Packard in 
establishing business relationships with Chinese corporations. In describing the nature of HewlettPackard's contractual relations with one of China's largest firms, Velasquez shows how it is possible for a foreign firm to contribute to both the economic and social well-being of individual constituents within the Chinese firms. Due to its long-term broadgauged policies, Hewlett-Packard gained a respected place in the growing economy of China.

In reporting their research on two foreign firms in China, one from Japan, the other from Taiwan, Krueger and Deng note the ways in which these two firms, each in their own way, deal with an interventionist government, resolve issues of equity and fairness, and confront business practices that rely heavily on exclusive social networks and quanxi relationships. In their case study, they find that these business firms have played a positive role in bringing about more equitable and open practices in contractual relations in China.

The final two case studies are of great interest, in that both document efforts by business interests to mount programs specifically designed to enhance human capital and thereby improve social conditions in general. Bird describes the way in which Placer Dome, a mining firm in South Africa funded an extensive project designed to facilitate self-employment for those workers the firm was forced to lay off. Raufflet's account of the origins of the Community Individual Development Association (CIDA) business training university in South Africa illustrates how a few highly motivated individuals, backed by a number of business firms, were able to provide post-secondary education training and thereby equip students with the skills for higher paid employment.

Readers will notice that in this collection of essays and case studies an awareness of the history of each local context is essential for understanding those issues that prompt ethical concerns. Crucial to this emphasis on history are the flows of influence and power among the institutions of government, the economy and civil society. When foreign firms enter this flow of social and economic interchanges, they are immediately confronted with the need to determine how they ought to respond. On one hand, they have a responsibility to further economic interests of their firms; on the other hand, they have an ethical obligation to conduct their business operations in a manner that improves, or at least does not degrade, the living conditions of the host countries.

In the final essay, Bird reflects on the significance of the historical perspective and the social context for the practice of business ethics. He argues that an awareness of national histories fosters an appreciation for local moral traditions; it provides an understanding of the background of contemporary crises; it reveals to current business leaders what actions are possible within the local setting and finally, it leads business leaders to think of ethical monitoring less as a rigid policing activity and more as a means to remain ethically grounded while remaining open and responsive to unique ethical exigencies. In taking seriously the historical trajectories of political, economic, and social institutions and the constellations of power that drives them, the practice of business ethics becomes an integral part of the strategy of business firms rather than remaining an after-thought.

\section{References}

Baker, R.: 2005, Capitalism's Achilles Heel: Dirty Money and How to Renew the Free-Market System (John Wiley and Sons, Hoboken, NJ).

Bird, F.: 2005, 'Businesses as Good Citizens', in G. Gad, S. B. Hiss, and T. Wienharedt (eds.), Wirtschaft, Ethik, unt Entwicklung (Der Wissenschaftiche Verlag, Berlin), Chap. 1, pp. 1-41.

Collier, P.: 2007, The Bottom Billion: Why the Poorest Countries are Failing and What Can Be Done About It (Oxford University Press, Oxford).

Drohan, M.: 2003, Making a Killing: How and Why Corporations Use Armed Force to do Business (Random House Canada, Toronto).

Easterly, W.: 2006, White Man's Burden: Why the West's Efforts to Aid the Rest Have Done So Much Ill and So Little Good (Penguin Press, New York).

Kinzer, S.: 2003, All the Shah's Men: An American Coup and the Roots of Middle East Terror (John Wiley and Sons, Hoboken, NJ).

Klein, N.: 2007, The Shock Doctrine: The Rise of Disaster Capitalism (Alfred Knopf Canada, Toronto).

Litvin, D.: 2003, Empires of Profit: Commerce, Conquest and Corporate Responsibility (Texere, New York). 
Sethi, S. P. and O. F. Williams: 2001, Economic Imperatives and Ethical Values in Global Business: The South African Experience and International Codes Today (University of Notre Dame Press, Notre Dame).

Smucker, J.: 2006, 'Pursuing Corporate Social Responsibility in Changing Institutional Fields', in F. Bird and M. Velasquez (eds.), Just Business Practices in a Diverse and Developing World (Palgrave Macmillan, Houndmills, UK), pp. 81-108.

Frederick Bird

Department of Political Science, University of Waterloo, 200 University West, Waterloo, ON, Canada E-mail:fbird@uwaterloo.ca
Joseph Smucker Department of Sociology, Concordia University, 1495 de Maisonneuve Blvd., Ouest, Montreal, QC H3G 1M8, Canada E-mail:smucker@alcor.ca

Manuel Velasquez Department of Management, Santa Clara University, Santa Clara, CA, U.S.A. E-mail: mvelasquez@scu.edu 